\title{
Anecdotal Response to Amphotericin in a Patient with Probable Susac Syndrome: Implications in the Pathogenesis
}

\section{Um Caso de Provável Síndrome de Susac com Resposta Anedótica à Anfotericina: Implicações na Patogénese}

\author{
Raquel GIL-GOUVEIA $\triangle^{1}$, Natália MARTO ${ }^{2}$, Pedro VILELA ${ }^{3}$, Ana CATARINO $^{4}$
}

Acta Med Port 2019 Nov32(11):727-730 - https://doi.org/10.20344/amp.10541

\section{ABSTRACT}

Susac syndrome is a rare, probably immune-mediated endotheliopathy presenting with encephalopathy, sensorineural hearing loss and retinal arterial occlusions. A 33-year-old female with Susac syndrome was worsening despite high-dose steroids so a brain biopsy was performed which suggested a possible fungal infection. Treatment with amphotericin B resulted in prompt reversal of symptoms and radiological findings, and no further symptoms occurred during 8 years of follow-up. A diagnosis of fungal infection was not confirmed. The etiology of Susac syndrome is unknown and this anecdotal observation suggests that an infectious agent susceptible to amphotericin might have caused or triggered Susac syndrome in this patient.

Keywords: Amphotericin B; Meningoencephalitis; Susac Syndrome

\section{RESUMO}

A síndrome de Susac é uma endoteliopatia rara, provavelmente imunomediada que se apresenta com a tríade sindromática de encefalopatia, surdez neurosensorial e oclusões de ramos arteriais da retina. Apresenta-se o caso de uma mulher de 33 anos com o diagnóstico de síndrome de Susac que agravou sob terapêutica imunossupressora, pelo que se decidiu pela realização de uma biópsia cerebral, que levantou a suspeita de uma possível infeção fúngica. O tratamento com anfotericina B resultou numa recuperação clínica e imagiológica rápida e não se verificou recorrência de sintomas num período de seguimento de oito anos. O diagnóstico de meningoencefalite fúngica não foi confirmado. A etiologia da síndrome de Susac é desconhecida. A observação fortuita da resposta terapêutica deste caso sugere que um agente infecioso suscetível à anfotericina B possa ter causado ou desencadeado esta síndrome, nesta doente.

Palavras-chave: Anfotericina B; Meningoencefalite; Síndrome de Susac

\section{INTRODUCTION}

Susac syndrome is a microangiopathy of uncertain pathogenesis causing small infarcts in the brain, cochlea and retina leading to the clinical triad of subacute encephalopathy, sensorineural hearing loss and branch retinal artery occlusions, although these features may not present simultaneously. ${ }^{1}$ It was proposed as a an immune-mediated endotheliopathy ${ }^{2}$ that may possibly be self-limited, ${ }^{3}$ even if most cases show a fluctuant course. ${ }^{4}$ Sequela are frequent, often mild, but cases of severe encephalopathy and resistance to treatment occur ${ }^{3-5}$ with dramatic outcomes. The usual treatment options include immunosuppression ${ }^{3}$ and antiplatelet agents or anticoagulation. ${ }^{4}$ We report the case of a patient with refractory Susac syndrome who was treated with amphotericin and had an outstanding recovery. We discuss the similarities of Susac syndrome with fungal meningoencephalitis and speculate about a potential role of an infectious agent as a trigger or in the pathogenesis.

\section{CASE REPORT}

A 33-year-old female developed a flu-like illness followed by persistent headache, cognitive decline with self-limited episodes of urinary incontinence and gait instability. One month later she developed encephalopathy, showing persistent gait apraxia, marked psychomotor slowness and frontal release signs. Initial diagnostic hypothesis included acute disseminated encephalomyelitis and meningoencephalitis. Initial blood routines were normal, and the protein level in the cerebrospinal fluid (CSF) was $85 \mathrm{mg} / \mathrm{dL}$. Initial empiric treatment with ceftriaxone $(2 \mathrm{~g} / \mathrm{d}, 2$ weeks) and a short course of methilprednisone $(1 \mathrm{~g} / \mathrm{d}, 5$ days) were started on admission, with clinical improvement.

Electroencephalography showed bilateral asymmetrical frontal slowing. The neuroaxis magnetic ressonance imaging (MRI) depicted typical lesions of Susac syndrome (Figs. $1 \mathrm{~A}, \mathrm{~B}, \mathrm{C}$ ) and the ophthalmological evaluation revealed a temporal arterial retinal branch infarct, confirmed by angiography. The audiogram and the auditory evoked potential test were normal, therefore this clinical presentation was compatible with the diagnosis of probable Susac syndrome. ${ }^{1}$

Normal laboratory testing included inflammatory markers, full panel of systemic auto-antibodies, angiotensin converting enzyme (ACE), lysozyme, serologies for

\footnotetext{
1. Department of Neurology. Hospital da Luz. Lisboa. Portugal.

2. Department of Internal Medicine. Hospital da Luz. Lisboa. Portugal.

3. Department of Neurorradiology. Hospital da Luz. Lisboa. Portugal.

4. Department of Pathology. Hospital da Luz. Lisboa. Portugal.

$\square$ Autor correspondente: Raquel Gil-Gouveia. rgilgouveia@gmail.com

Recebido: 18 de março de 2018 - 09 de outubro de 2018| Copyright @ Ordem dos Médicos 2019
} 

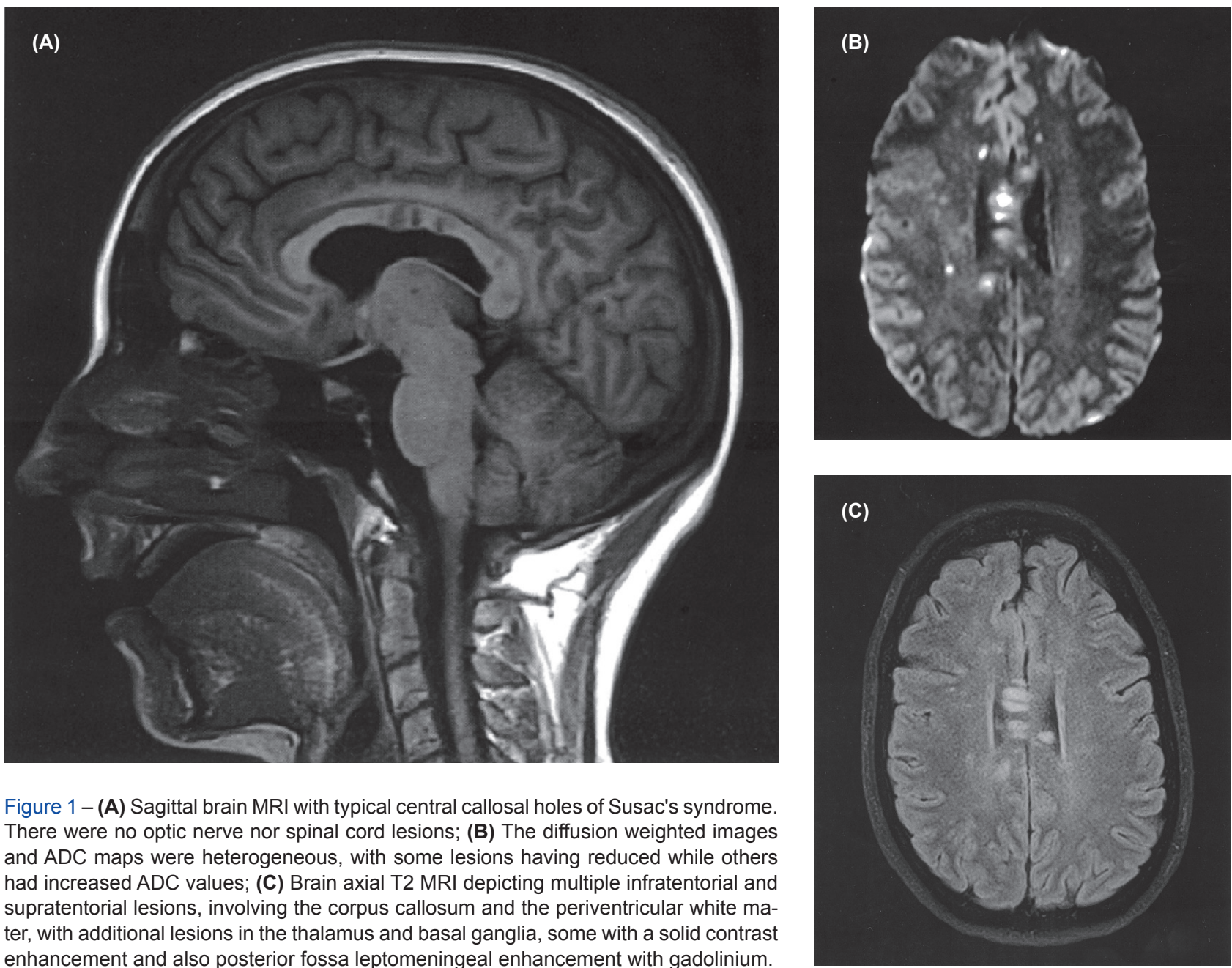

Figure 1 - (A) Sagittal brain MRI with typical central callosal holes of Susac's syndrome. There were no optic nerve nor spinal cord lesions; (B) The diffusion weighted images and ADC maps were heterogeneous, with some lesions having reduced while others had increased ADC values; (C) Brain axial T2 MRI depicting multiple infratentorial and supratentorial lesions, involving the corpus callosum and the periventricular white mater, with additional lesions in the thalamus and basal ganglia, some with a solid contrast enhancement and also posterior fossa leptomeningeal enhancement with gadolinium.

Due to the possibility of a dimorphic fungus, amphotericin B (1 mg/kg, $8 \mathrm{~g}$ total) was started during the $8^{\text {th }}$ week and prednisone was tapered in the following two weeks while waiting for the electronic microscopy result. Clinical improvement was noted after 48 hours, and full clinical recovery occurred at the $12^{\text {th }}$ week when MRI showed marked reduction of the number and size of the brain lesions and resolution of the leptomeningeal enhancement. The patient was discharged during the $16^{\text {th }}$ week, and returned to her normal life without limitations and has been followed up yearly since then. She remains well after eight years of follow-up, having had a successful pregnancy two years ago.

\section{DISCUSSION}

This young healthy female presented with subacute onset encephalopathy after a flu-like illness in which the MRI showed typical brain lesions of Susac syndrome, ${ }^{2,6}$ high protein content in CSF and an asymptomatic arterial retinal branch infarct, without auditory involvement - the most frequent inaugural symptoms ${ }^{4}$ fulfilling the proposed diagnostic criteria for probable Susac syndrome. ${ }^{1}$ Although an initial response to steroids was observed, it was followed by persistent clinical decline unrelated to complications 
of steroid therapy, and that has been described by Susac et al, ${ }^{3-5}$ and usually implies escalation to aggressive immunosuppression. ${ }^{3}$ An angiography and biopsy were undertaken to evaluate the possibility of primary angitis of the central nervous system although the MRI had not shown hemorrhagic lesions. Angiography revealed very mild focal callosal abnormalities and histological analysis casted doubts about the possibility of a dimorphic fungus, as there were no signs of vessel wall damage. ${ }^{7}$ Considering the catastrophic clinical worsening, amphotericin was started, steroids were tapered and a fast and dramatic clinical and radiological improvement ensued, and this argued against a possible spontaneous remission or a delayed steroid effect. ${ }^{4,8}$ Electron microscopy confirmed the presence of corpora amylacea-like bodies, described by Susac et al ${ }^{9}$ and these were associated with antifungal antibodies. ${ }^{10}$ Corpora amylacea are glycoproteinaceous structures that are found in aged, normal human brains, but also in several diseases, in particular neurodegenerative or infectious/ inflammatory conditions. Recent evidence suggests that these structures are part of an organized physiological cleaning process in the central nervous system, serving as 'waste containers'. ${ }^{11}$ Brain tissue cultures were not done, which is the major limitation against being able establish a definitive diagnosis. The yield of a positive fungal culture in fungal meningoencephalitis is lower than $50 \%$, even with repeated CSF sampling as was done, so it often remains a presumptive diagnosis ${ }^{12}$ - nevertheless, there was never pleocytosis in 7 repeated CSF analysis. All the clinical and para-clinical data of this case supported the diagnosis of Susac syndrome, except for the anecdotal response to amphotericin. This fortuitous observation leads to speculation - could this have been a fungal encephalomeningitis? Or could a fungal (or other amphotericin responsive) agent might have triggered an immune response simulating a Susac-like syndrome in our patient? Or even less likely, could Susac syndrome have been caused by an amphotericin-responsive agent? Or could Susac sydrome have responded to amphotericin due to an unknown mechanism?

The etiology of Susac syndrome is unknown, although the finding of anti-endothelial cell antibodies (AECA) in some patients ${ }^{5}$ suggests an immunological humoral inflammation of the microvascular endothelium. A study of AECA in a large clinical sample of patients with Susac syndrome did not find an association of high-titer IgG1 and IgM AECA with clinical data, response to treatment nor outcome, so these antibodies may represent an epiphenomenon of endothelial damage of other origin. ${ }^{13}$

Susac syndrome has similarities to fungal meningoencephalitis, such as seasonal occurrence, ${ }^{4}$ preceding flu-like illness, ${ }^{4,5}$ discrepancy between clinical manifestations and imaging features, ${ }^{4,6}$ lack of well-defined clinical course with some spontaneous remissions, ${ }^{4}$ difficulties in predicting response to immunosuppressive treatment ${ }^{3,4}$ and relapses during pregnancy and postpartum. ${ }^{4} \mathrm{~A}$ few Susac-like cases have been described in patients at high risk for CNS fungal disease - an HIV patient ${ }^{14}$ and an individual with cocaine addiction, ${ }^{15}$ the first having and indolent course with CD4 recovery while the second had an unfavorable outcome, despite maximal immunosuppressive therapy.

The course of Susac syndrome is either monophasic and self-limiting, polycyclic or chronic continuous; however, the definition of the disease course is complex as treatment strategies and follow-up periods vary considerably in published reports. ${ }^{2}$ We have to consider the hypothesis of the simultaneous occurrence of a spontaneous remission with the introduction of amphotericin in our patient. However, the average symptom duration described before remission in Susac syndrome is two years and often residual symptoms persist. ${ }^{3}$ In our case, the complete and fast inversion of the clinical worsening tendency that persisted for eight weeks despite adequate treatment had a close temporal relationship of days with the change in treatment course, casting doubts of it being an occasional coincidental finding. Our long completely symptom free follow-up period of eight years favors either a monophasic infectious illness or a monophasic Susac syndrome; the occurrence of an uncomplicated pregnancy without relapses in our patient argues against Susac syndrome.

\section{ACKNOWLEDGMENTS}

The authors would like to acknowledge significant contribution to clinical discussion and daily clinical support from the medical team in Hospital da Luz, especially Paulo Martins Campos (Ophthalmology) who studied the ophthalmological manifestations, Manuel Cunha e Sá (Neurosurgery) who performed the brain biopsy and also to José Ferro for helpful input on differential diagnosis.

We also like to acknowledge the helpful input that Jan Markus Dörr made to the discussion of this report.

This case report was awarded the $2^{\text {nd }}$ António Flores award, for poster presentations, at the Portuguese Neurological Society Congress in 2009.

\section{PROTECTION OF HUMANS AND ANIMALS}

The authors declare that the procedures were followed according to the regulations established by the Clinical Research and Ethics Committee and to the Helsinki Declaration of the World Medical Association.

\section{DATA CONFIDENTIALITY}

The authors declare having followed the protocols in use at their working center regarding patients' data publication.

\section{PATIENT CONSENT}

Obtained.

\section{CONFLICTS OF INTEREST}

All authors report no conflict of interest.

\section{FUNDING SOURCES}

This research did not receive any specific grant from funding agencies in the public, commercial, or not-for-profit sectors. 


\section{REFERENCES}

1. Kleffner I, Dörr J, Ringelstein M, Gross CC, Böckenfeld Y, Schwindt W, et al. Diagnostic criteria for Susac syndrome. J Neurol Neurosurg Psychiatry. 2016;87:1287-95.

2. Dörr J, Krautwald S, Wildemann B, Jarius S, Ringelstein M, Duning T, et al. Characteristics of Susac syndrome: a review of all reported cases. Nat Rev Neurol. 2013:9:307-16.

3. Rennebohm R, Egan R, Susac J. Treatment of Susac's syndrome. Curr Treat Options Neurol. 2008;10:67-74.

4. Aubart-Cohen F, Klein I, Alexandra J. Long-term outcome in Susac syndrome. Medicine. 2007;86:93-102.

5. Susac J, Egan R, Rennebohm R, Lubow M. Susac's syndrome: 1975-2005 microangiopathy/autoimmune endotheliopathy. J Neurol Sci. 2007;257:270-2

6. Susac J, Murtagh F, Egan R. MRI findings in Susac's syndrome. Neurology. 2003;61:1783-7.

7. Powers WJ. Primary angiitis of the central nervous system: diagnostic criteria. Neurol Clin. 2015;33:515-26.

8. Krieger S, Sorrells SF, Nickerson M, Pace TW. Mechanistic insights into corticosteroids in multiple sclerosis: war horse or chameleon? Clin Neurol Neurosurg. 2014;119:6-16.
9. McLeod DS, Ying HS, McLeod CA, Grebe R, Lubow M, Susac JO, et al. Retinal and optic nerve head pathology in Susac's syndrome. Ophthalmology. 2010;118:548-52.

10. Pisa D, Alonso R, Rábano A, Carrasco L. Corpora amylacea of brain tissue from neurodegenerative diseases are stained with specific antifungal antibodies. Front Neurosci. 2016;10:86.

11. Augé E, Cabezón I, Pelegrí C, Vilaplana J. New perspectives on corpora amylacea in the human brain. Sci Rep. 2017;7:41807.

12. Davis L. Fungal infections of the central nervous system. Neurol Clin. 1999;17:761-81.

13. Jarius S, Kleffner I, Dörr JM, Sastre-Garriga J, Illes Z, Eggenberger E, et al. Clinical, paraclinical and serological findings in Susac syndrome: an international multicenter study. J Neuroinflammation. 2014;11:46.

14. Longbrake EE, Ances BM, Viets RB, Clifford DB. Susac syndrome in a patient with human immunodeficiency virus infection. J Neurovirol. 2013;19:270-3.

15. Hantson $P$, Di Fazio $V$, Del Mar Ramirez Fernandez M, Samyn N, Duprez T, van Pesch V. Susac-like syndrome in a chronic cocaine abuser: could levamisole play a role? J Med Toxicol. 2015;11:124-8.

\section{Daniela GONCALVESM11 Marcilia TEIXEIRA². Rosa RODRIGUES³. Jorge BRAGA
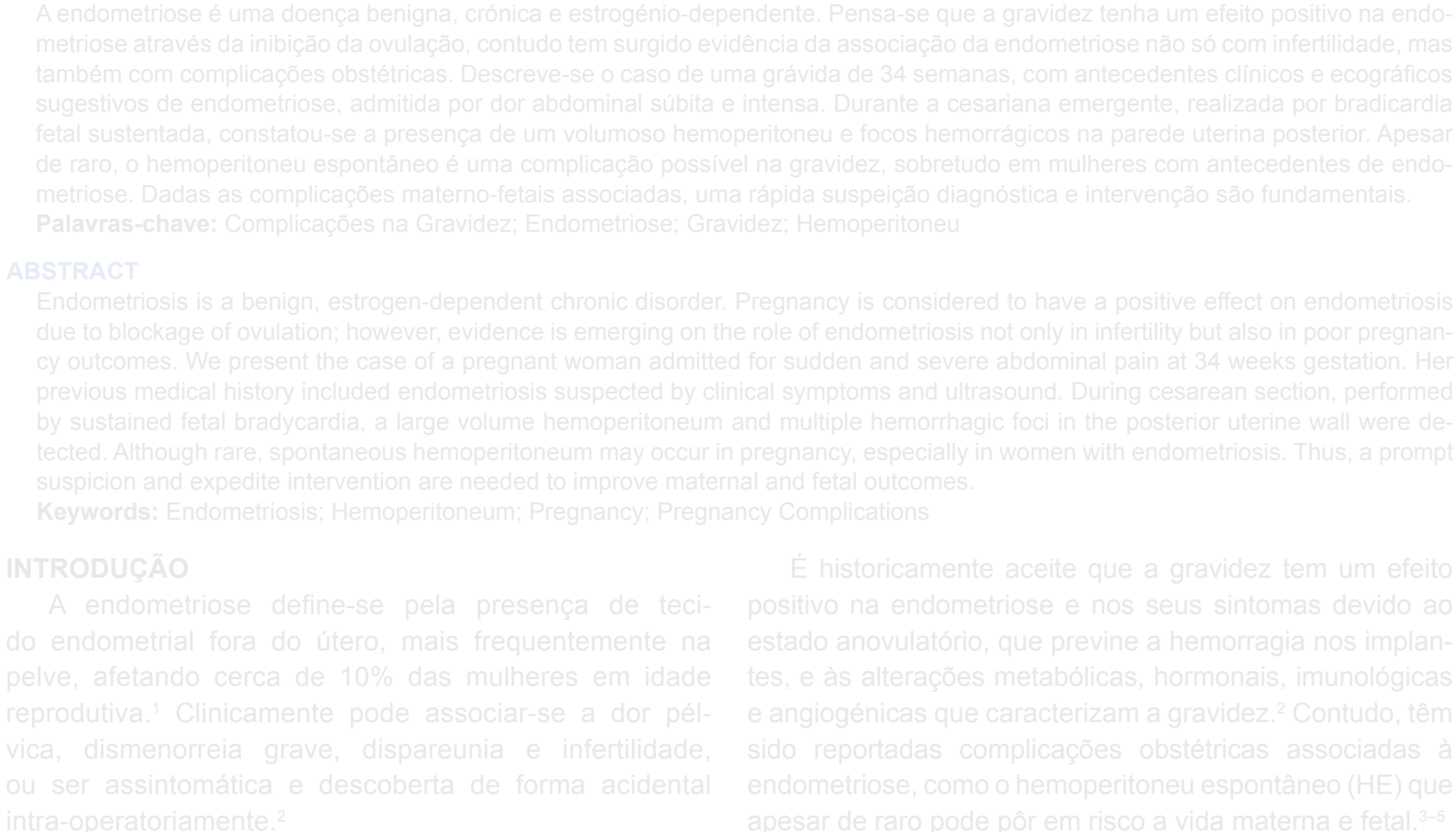